\title{
$\mathrm{ZrO}_{2}-\mathrm{SiO}_{2}$ 복합산화물에 담지된 백금 촉매의 요오드화수소 분해 특성 연구 \\ 고윤기 ${ }^{1} \cdot$ 박은정 $^{1,2} \cdot$ 배기광 $^{1 \dagger} \cdot$ 박주식 $^{1} \cdot$ 강경수 $^{1} \cdot$ 조원철 $^{1} \cdot$ 정성욱 $^{1} \cdot$ 김창희 $^{1} \cdot$ 김영호 $^{2}$ \\ ${ }^{1}$ 한국에너지기술연구원, ${ }^{2}$ 충남대학교
}

\section{A Study on Characteristics of HI Decomposition Using Pt Catalysts on $\mathrm{ZrO}_{2}-\mathrm{SiO}_{2}$ Mixed Oxide}

\author{
YUNKI KO ${ }^{1}$, EUNJUNG PARK ${ }^{1,2}$, KIKWANG BAE $^{1 \dagger}$, CHUSIK PARK $^{1}$, KYOUNGSOO KANG $^{1}$, \\ WONCHUL $\mathrm{CHO}^{1}$, SEONGUK JEONG ${ }^{1}$, CHANGHEE KIM ${ }^{1}$, YOUNG HO KIM ${ }^{2}$ \\ ${ }^{1}$ Hydrogen and Fuel Cell Department, Korea Institute of Energy Research, \\ 71-2 Jang-dong Yuseong-gu Daejeon 305-343, Korea \\ ${ }^{2}$ Department of Industrial Chemistry, Chungnam National University, \\ 220 Gung-dong Yuseong-gu Daejeon 305-764, Korea
}

\begin{abstract}
This work is investigated for the catalytic decomposition of hydrogen iodide (HI). Platinum was used as active material by loading on $\mathrm{ZrO}_{2}-\mathrm{SiO}_{2}$ mixed oxide in $\mathrm{HI}$ decomposition reaction. To obtain high and stable conversion of hydrogen iodide in severe condition, it was required to improve catalytic activity. For this reason, a method increasing dispersion of platinum was proposed in this study. In order to get high dispersion of platinum, zirconia was incorporated in silica by sol-gel synthesis. Incorporating zirconia influence increasing platinum dispersion and BET surface area as well as decreasing deactivation of catalysts. It should be able to stably product hydrogen for a long time because of inhibitive deactivation. HI decomposition reaction was carried out under the condition of $450^{\circ} \mathrm{C}$ and $1 \mathrm{~atm}$ in a fixed bed reactor. Catalysts analysis methods such as $\mathrm{N}_{2}$ adsorption/desorption analysis, X-ray diffraction, X-ray fluorescence, ICP-AES and CO gas chemisorption were used to measurement of their physico-chemical properties.
\end{abstract}

Key words : Hydrogen iodide decomposition(요오드화수소 분해), Pt catalyst(백금 촉매), Metal dispersion(금속 분산도), Metal-support interaction(금속-지지체 간 상호작용)

\section{Superscripts}

I : ICP-AES analysis

$\mathrm{X}: \mathrm{XRF}$ analysis

\footnotetext{
${ }^{\dagger}$ Corresponding author : kkbae@kier.re.kr

[ 접수일 : 2013.8.9 수정일 : 2013.10.16 게재확정일 : 2013.10.31 ]

Copyright (c) 2013 KHNES
}

c : commercial silica support

sg : synthesized support by sol-gel method

\section{1. 서 론}

물은 수소를 생산할 수 있는 대표적 청정에너지 자원이다. 다양한 방법을 통해 물로부터 수소를 생산 할 수 있으며 순환사용이 가능하다. 수소 생산에 있 
어 물의 단순 열분해는 $4273 \mathrm{~K}$ 이상의 반응 온도가 필요하고 내열용기의 확보가 어려운 문제점이 제기 되어 열화학 싸이클 반응을 통한 간접적인 생산이 요구된다. 물 분해를 위한 대표적 열화학 싸이클 반 응은 황-요오드 공정(S-I process)이 있으며, 다음의 3 단계 반응으로 구성된다 ${ }^{1,2)}$.

$$
\begin{aligned}
& \mathrm{SO}_{2}+\mathrm{I}_{2}+2 \mathrm{H}_{2} \mathrm{O} \rightarrow \mathrm{H}_{2} \mathrm{SO}_{4}+2 \mathrm{HI} \\
& 2 \mathrm{HI} \rightarrow \mathrm{H}_{2}+\mathrm{I}_{2} \\
& \mathrm{H}_{2} \mathrm{SO}_{4} \rightarrow \mathrm{H}_{2} \mathrm{O}+\mathrm{SO}_{2}+0.5 \mathrm{O}_{2}
\end{aligned}
$$

식 (1)은 분젠(Bunsen) 반응단계로써 물이 이산화 황 및 요오드와 반응하여 황산 $\left(\mathrm{H}_{2} \mathrm{SO}_{4}\right.$, sulfuric acid) 과 요도드화수소산(HI, hydriodic acid)을 생성한다. 생성된 황산과 요오드화수소산은 밀도 차에 의한 분 리가 가능하며, 분리된 황산 용액과 요오드화수소산 용액은 각각의 분해반응 단계로 전달된다. 식 (3)의 황산 분해단계에서 물, 이산화황, 산소를 생성하며, 식 (2)의 요오드화수소 분해단계에서 수소와 요오드 를 생성하게 된다. 각 단계에서 분해된 최종 생성물 중 산소와 수소를 제외한 분해 생성물들은 분젠 반 응으로 재순환되어 폐싸이클 반응을 이룬다. 결과적 으로 황-요오드 공정은 물을 공급하여 수소와 산소 를 분리하는 공정이 된다.

수소의 직접적인 생산이 이루어지는 요오드화수 소산 분해반응 단계는 전체 공정의 열효율을 고려한 다면 약 $427 \sim 527{ }^{\circ} \mathrm{C}$ 의 조건에서 운전되어야 하지만, 단순 열분해만으로는 반응속도가 느리기 때문에 촉 매의 이용이 불가피하다 ${ }^{3)}$. 요오드화수소의 분해반응 은 요오드화수소산의 강한 산성과 고온반응 조건 때 문에 촉매의 내부식성과 열적안정성이 요구된다. 기 존 연구에 의하면, 활성금속으로 백금, 니켈, 이리듐, 팔라듐 등의 전이금속이 알루미나 $\left(\mathrm{Al}_{2} \mathrm{O}_{3}\right)$, 실리카 $\left(\mathrm{SiO}_{2}\right), \mathrm{SBA}-15$, 세리아 $\left(\mathrm{CeO}_{2}\right)$, 활성탄소 등의 지지
체에 담지되어 $\mathrm{HI}$ 분해반응이 수행되었다 ${ }^{3-9)}$.

본 연구팀은 이전 연구에서 실리카, 알루미나, 지 르코니아 $\left(\mathrm{ZrO}_{2}\right)$, 세리아 지지체에 따른 백금 촉매의 활성 실험을 통하여 $\mathrm{Pt} / \mathrm{Al}_{2} \mathrm{O}_{3}$ 촉매가 우수한 성질 및 활성을 갖는다고 보고하였다 ${ }^{10)}$. 이는 백금과 알루미 나의 강한 상호작용에 의한 것으로 나타났다 ${ }^{11}$. 비교 적 높은 비표면적을 갖는 실리카에서 높은 백금 분 산도를 예상 하였으나, 백금과 실리카의 낮은 상호작 용으로 낮은 분산도가 나타났고, 고온 반응에 의한 비활성화를 보였다 ${ }^{12,13)}$. 실리카는 산화물 중 화학적, 열적으로 안정한 물질이기 때문에 지지체로써 적합 한 성질을 가지고 있을 뿐만 아니라, 제조방법 및 조 건에 따라 비표면적을 증가시키기 용이하다. 만약, 실리카 지지체와 백금 간의 상호작용 및 비표면적을 증가시켜 백금의 분산도를 증가 시킬 수 있다면 우 수한 촉매 성능을 보일 것으로 예상할 수 있다.

$\mathrm{Kim}$ 등 $^{14-16)}$ 은 $\mathrm{Pt} / \mathrm{SiO}_{2}$ 에 산화물을 첨가하여 백금 의 높은 분산도를 얻을 수 있으며, 금속-지지체 간의 상호작용을 강화 시킬 수 있다고 보고하였다. Kim 등은 타이타니아 $\left(\mathrm{TiO}_{2}\right)$, 바나디아 $\left(\mathrm{V}_{2} \mathrm{O}_{3}\right)$, 지르코니아, 세리아를 실리카에 첨가하였고, 이들 중에 지르코니 아를 고정한 실리카 지지체에서 백금의 높은 분산도 를 보였다고 보고하였다. 이는 Pt-O-Zr 결합의 형성 으로 인한 백금의 분산도와 안정성이 증진되기 때문 이라고 보고하고 있다 ${ }^{15)}$. 실리카 지지체의 비표면적 및 세공의 물성 변화를 위해, Lee 등 ${ }^{17}$ 은 sol-gel 방법 에 의한 실리카 제조과정에서 담지금속을 첨가하는 방법을 제시하였다. Lee 등은 sol-gel 과정 중에 백금 전구체를 첨가하여 백금 입자를 고르게 분산시킬 수 있으며, 백금 전구체의 농도를 조절함으로써 비표면 적 및 세공 물성의 변화를 확인하였다.

본 실험에서는 실리카 지지체를 기반으로 다양한 방법으로 백금 촉매를 제조하여 각 촉매의 물성 분 석 및 요오드화수소산 분해반응 활성에 대한 평가를 수행하였다. 실리카의 sol-gel 합성법을 이용하여 지 
르코니아가 첨가된 $\mathrm{ZrO}_{2}-\mathrm{SiO}_{2}$ 지지체를 제조하였으 며, 지르코니아 전구체의 첨가 농도에 따른 $\mathrm{BET}$ 비 표면적의 변화를 확인하였고, 제조된 $\mathrm{ZrO}_{2}-\mathrm{SiO}_{2}$ 지지 체에 담지된 백금의 분산도 및 활성변화를 관찰하였다.

\section{2. 실 험}

\section{1. 촉매 제조}

백금 촉매에 사용된 지지체는 네 종류가 있으며, 각 지지체에 따른 백금 촉매 제조방법도 네 가지이다. 모든 촉매는 함침법을 이용하여 $0.5 \mathrm{wt} \%$ 백금을 담지 되었고, 각 지지체에 담지 되는 백금 전구체는 tetra amine platinum(II) nitrate (Sigma-Aldrich, 99.995\%) 이다. 제조된 백금 촉매의 제조 방법 및 함량은 Table 1 에 나타냈다.

네 종류의 지지체 중, 상용 실리카(Alfa-Aesar, 99\%) 를 이용하여 $\mathrm{Pt} / \mathrm{SiO}_{2}{ }^{\mathrm{c}}$ (이하 $\mathrm{PS}^{\mathrm{c}}$ ) 촉매를 제조하는 방 법은 다음과 같다. 펠릿 형태의 상용지지체를 분쇄하

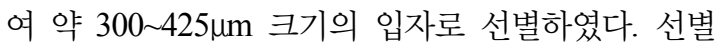
된 실리카 지지체에 백금을 함침한 후에, $50 \mathrm{vol} . \%$ $\mathrm{H}_{2} / \mathrm{Ar}$ 기체로 $400^{\circ} \mathrm{C}$ 에서 2시간 환원하였다(이하 방 법 1).

$\mathrm{Pt} / \mathrm{SiO}_{2}{ }^{\mathrm{sg}}$ (이하 $\mathrm{PS}^{\mathrm{sg}}$ ) 촉매의 실리카 지지체는 sol-gel 합성법을 이용하여 제조되었으며, 실리카의 전구체 로 TEOS(tetraethyl orthosilicate, 99.9\%, Sigma-Aldrich) 를 이용하였다. 이 때 반응물의 몰비는 TEOS : ethanol $: \mathrm{H}_{2} \mathrm{O}: \mathrm{NH}_{3}=1: 40.7: 53.6: 0.09$ 이다. 반응물을 $50{ }^{\circ} \mathrm{C}$ 에서 3 시간 교반 후 $1 \mathrm{M}$ 질산 용액으로 $\mathrm{pH}$ 를 6.25로 조절하여 colloidal sol을 형성시켰다. Colloidal $\mathrm{sol}$ 은 $100^{\circ} \mathrm{C}$ 오븐에서 24 시간 건조 후, $700^{\circ} \mathrm{C}$ 에서 6 시간 동안 소성시켰다. 이 후 과정은 방법 1과 비슷 하게 분쇄, 선별, 함침, 환원의 과정을 거쳐 제조되었 다(이하 방법 2).

$\mathrm{Pt} / \mathrm{ZrO}_{2}-\mathrm{SiO}_{2}$ 촉매의 지지체는 두 가지 방법에 의 해 제조된다. 첫 번째 방법은 $\mathrm{Kim}$ 등 $^{15)}$ 이 제조한 방
Table 1 The list of Pt catalysts prepared by various methods

\begin{tabular}{|c|c|c|c|}
\hline Catalysts & $\begin{array}{l}\text { Preparation } \\
\text { method }\end{array}$ & $\begin{array}{l}\text { Platinum } \\
\text { contents } \\
\left(\mathrm{wt}^{\mathrm{I}} \%\right)\end{array}$ & $\begin{array}{l}\text { Zirconia contents } \\
\quad\left(\mathrm{wt}^{\mathrm{X}} \mathrm{x}^{\mathrm{X}}\right)\end{array}$ \\
\hline $\mathrm{PS}^{\mathrm{c}}$ & Method 1 & 0.39 & \multirow{2}{*}{ none } \\
\hline $\mathrm{PS}^{\mathrm{sg}}$ & Method 2 & 0.45 & \\
\hline $\mathrm{PZ}(20) \mathrm{S}^{\mathrm{c}}$ & Method 3 & 0.42 & 19.6 \\
\hline $\mathrm{PZ}(10) \mathrm{S}^{\mathrm{sg}}$ & \multirow{4}{*}{ Method 4} & 0.51 & 9.5 \\
\hline $\mathrm{PZ}(20) \mathrm{S}^{\mathrm{sg}}$ & & 0.31 & 19.7 \\
\hline $\mathrm{PZ}(30) \mathrm{S}^{\mathrm{sg}}$ & & 0.45 & 37.9 \\
\hline $\mathrm{PZ}(40) \mathrm{S}^{\mathrm{sg}}$ & & 0.46 & 49.6 \\
\hline
\end{tabular}

c : commercial support

sg: sol-gel synthesized support

I : ICP-AES analysis

$\mathrm{X}: \mathrm{XRF}$ analysis

법과 유사하다. $\mathrm{Zr} / \mathrm{Si}$ 의 비를 0.2 로 하여 zirconium propoxide (Sigma-Aldrich, 99.9\%)를 에탄올(OCI, 99.9\%) 에 용해시킨 후, 분쇄된 상용 실리카를 zirconium propoxide 용액에 투입하여 $80^{\circ} \mathrm{C}$ 에서 4 시간동안 반 응 시켰다. 세척과 건조, 소성 처리 후 백금을 담지시 켜 $\mathrm{Pt} / \mathrm{ZrO}_{2}(20 \mathrm{wt} \%)-\mathrm{SiO}_{2}{ }^{\mathrm{c}}$ (이하 $\left.\mathrm{PZ}(20) \mathrm{S}^{\mathrm{c}}\right)$ 촉매를 제 조하였다(이하 방법 3).

두 번째 방법은 방법 2의 실리카 합성방법을 기초 로, $\mathrm{pH}$ 조절 이전에 zirconium propoxide를 투입하여 $\mathrm{Pt} / \mathrm{ZrO}_{2}(10 \sim 40 \mathrm{wt} \%)-\mathrm{SiO}_{2}$ (이하 $\mathrm{PZ}(10 \sim 40) \mathrm{S}^{\mathrm{sg}}$ 촉매를 제조하는 방법이다. Zirconium propoxide는 $\mathrm{Zr} / \mathrm{Si}$ 비 를 0.1 0.4의 비율로 첨가하였고, 이 후의 제조 과정 은 방법 2와 같이 건조, 소성, 분쇄, 선별, 함침, 환원 의 과정을 거쳐 $\mathrm{PZ}(10 \sim 40) \mathrm{S}^{\mathrm{sg}}$ 촉매를 제조하였다(이 하 방법 4).

\section{2. 촉매 특성 분석}

제조된 촉매의 비표면적을 측정하기위해 질소 흡 탈착 분석(BELSORP-mini, BEL)을 실행하였으며, 백금의 분산도는 일산화탄소 기체 화학흡착(BELCAT$\mathrm{B}, \mathrm{BEL}$ ) 방법을 통하여 측정되었다. 담지된 백금의 결정상 및 결정 크기를 비교하기 위해 $\mathrm{X}$ 선 회절분석 
(X-ray diffraction, DMAX-2500, Rigaku)을 실행하였 다. 각 촉매에 담지된 백금 함량은 유도결합플라즈마 -원자방출분광기(ICP-AES, Perkin-Elmer)를 이용하 여 측정하였고, 지르코니아의 함량은 $\mathrm{X}$ 선 형광분석 기(X-ray fluorescence, ZSX Primus II, Rigaku)를 이 용하여 측정되었다.

\section{3. 요오드화수소 분해 실험}

$\mathrm{HI}$ 분해반응을 위한 장치는 Fig. 1에 나타내었다. $\mathrm{HI}$ 분해반응을 위해 길이는 $200 \mathrm{~mm}$, 내경은 $0.9 \mathrm{~mm}$ 인 고정층 반응기를 사용하였으며, 반응기는 고온 반 응과 요오드화수소에 대한 내부식성을 고려하여 석 영관을 사용하였다. 요오드화수소 산 용액과 아르곤 기체의 유속은 각각 $0.2 \mathrm{ml} / \mathrm{min}, 50 \mathrm{ml} / \mathrm{min}$ 이다. 요오 드화수소 산 용액과 아르곤 기체는 각각 정량 이송 펌프(Masterflex L/S digital drive, Cole-Parmer)와 MFC (mass flow controller, 1179A, MKS)를 이용하여 반 응장치의 하단부로 공급된다. 촉매층은 석영관에 고 정된 유리 필터 위에 석영솜-촉매-석영솜-SiC honeycomb 순으로 쌓았으며, 사용된 촉매의 양은 $0.4 \mathrm{~g}$ 이다. $\mathrm{HI}$ 분해반응 온도는 $450^{\circ} \mathrm{C}$ 이며, 촉매층을 제외한 나머 지 부분은 silicone oil을 순환시켜 $160^{\circ} \mathrm{C}$ 로 유지하였 다. 반응기 하단 부분은 공비조성의 요오드화수소 산

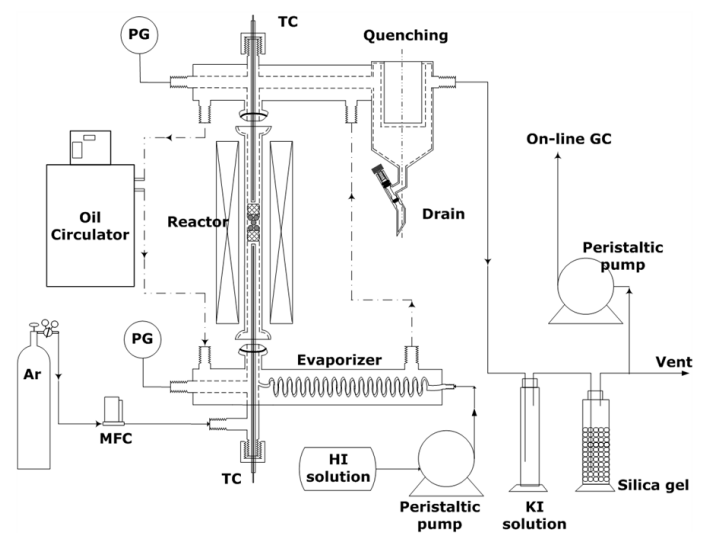

Fig. 1 Schematic diagram for catalytic $\mathrm{HI}$ decomposition apparatus
용액을 기화시키기 위한 부분이고, 상단부분은 반응 기체들을 응축시키는 부분이다. 응축기를 지난 반응 기체는 요오드화칼륨 수용액과 실리카겔을 지나 수 소와 아르곤 혼합기체로 분리된다. 분리된 수소와 아 르곤은 GC-TCD (gas chromatography-thermal conductivity detector, 7890A, Agilent technologies)로 분석되며, 이를 이용하여 전환율을 계산하였다.

\section{3. 결과 및 고찰}

\section{1. 촉매 특성 분석}

질소 흡탈착 분석법에 의해 나타난 결과, 상용 실 리카를 사용한 촉매의 BET 비표면적은 약 234,239 $\mathrm{m}^{2} / \mathrm{g}$ 이며, sol-gel 합성법으로 제조된 촉매는 437 576 $\mathrm{m}^{2} / \mathrm{g}$ 로 비표면적이 2 배 이상 큰 것으로 나타났다. $\mathrm{PZ}(10 \sim 40) \mathrm{S}^{\mathrm{sg}}$ 촉매는 지르코니아 함량에 따른 $\mathrm{BET}$ 비표면적 변화가 있었다.

$\mathrm{PS}^{\mathrm{c}}, \mathrm{PS}^{\mathrm{sg}}, \mathrm{PZ}(20) \mathrm{S}^{\mathrm{c}}, \mathrm{PZ}(10 \sim 40) \mathrm{S}^{\mathrm{sg}}$ 의 일산화탄소 기체 화학흡착법과 질소 흡, 탈착 방법을 통해 얻어 진 물성을 Table 2에 나타내었다. $\mathrm{PS}^{\mathrm{c}}$ 와 $\mathrm{PZ}(20) \mathrm{S}^{\mathrm{c}}$ 는 다른 촉매들 보다 낮은 비표면적을 갖지만, $\mathrm{PZ}(20) \mathrm{S}^{\mathrm{c}}$ 는 지르코니아 첨가에 의한 백금 분산도 증가를 확 인할 수 있었다. $\mathrm{PS}^{\mathrm{c}}$ 와 $\mathrm{PS}^{\mathrm{sg}}$ 를 비교하였을 때, sol-gel 합성으로 증가된 비표면적에 기인하여 백금의 분산

Table 2 CO gas chemisorption analysis of each catalyst

\begin{tabular}{c|c|c|c|c}
\hline \hline Catalysts & $\begin{array}{c}\mathrm{SBET} \\
\left(\mathrm{m}^{2} / \mathrm{g}\right)\end{array}$ & $\begin{array}{c}\mathrm{Dm} \\
(\%)\end{array}$ & $\begin{array}{c}\mathrm{Sm} \\
\left(\mathrm{m}^{2} / \mathrm{g}\right)\end{array}$ & $\begin{array}{c}\text { Pavg. } \\
(\mathrm{nm})\end{array}$ \\
\hline $\mathrm{PS}^{\mathrm{c}}$ & 234 & 1.8 & 4.4 & 62.8 \\
\hline $\mathrm{PS}^{\mathrm{sg}}$ & 437 & 10.6 & 26.2 & 10.7 \\
\hline $\mathrm{PZ}(20) \mathrm{S}^{\mathrm{c}}$ & 239 & 17.9 & 44.2 & 6.3 \\
\hline $\mathrm{PZ}(10) \mathrm{S}^{\mathrm{sg}}$ & 525 & 13.4 & 33.1 & 8.4 \\
\hline $\mathrm{PZ}(20) \mathrm{S}^{\mathrm{sg}}$ & 576 & 20.5 & 50.6 & 5.5 \\
\hline $\mathrm{PZ}(30) \mathrm{S}^{\mathrm{sg}}$ & 541 & 18.9 & 46.7 & 6.0 \\
\hline $\mathrm{PZ}(40) \mathrm{S}^{\mathrm{sg}}$ & 507 & 15.4 & 38.0 & 7.3 \\
\hline
\end{tabular}

$\mathrm{D}_{\mathrm{m}}$ : Metal dispersion of platinum

$\mathrm{S}_{\mathrm{m}}$ : Specific surface area of platinum $\mathrm{P}_{\text {avg. }}$ : Average particle size of platinum 


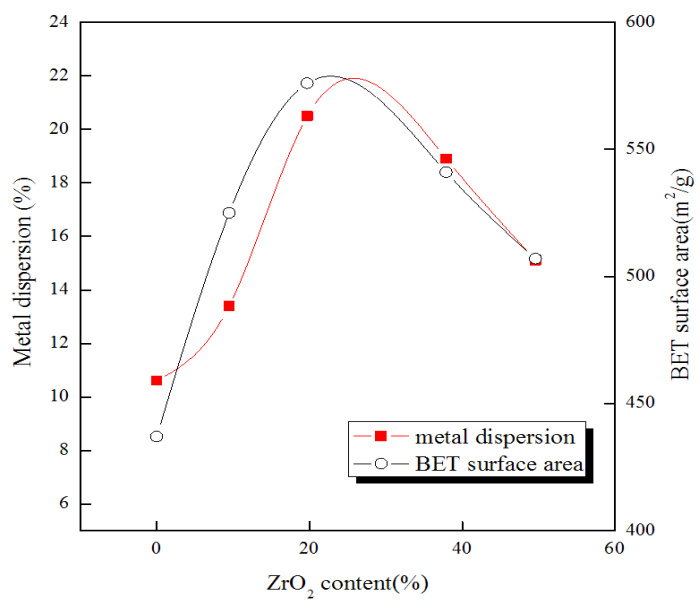

Fig. 2 Variations in metal dispersion(squares) and BET surface area(circles) function of $\mathrm{ZrO}_{2}$ content of catalysts made by Method 4

도가 증가하였다. 즉, 백금의 분산도는 지르코니아의 첨가와 촉매의 비표면적에 영향을 받는다는 것을 알 수 있다. 또한, 실리카의 sol-gel 합성 중 지르코니아 를 첨가함으로써 촉매의 비표면적을 $70 ~ 139 \mathrm{~m}^{2} / \mathrm{g}$ 가 량 증가시킬 수 있었다.

Fig. 2를 보면 방법 4에 의해 제조된 촉매들은 지 르코니아 함량에 따른 BET 비표면적 변화와 백금 분산도 변화가 유사함을 알 수 있다. $\mathrm{PZ}(20) \mathrm{S}^{\mathrm{sg}}$ 촉매 의 지르코니아가 함량이 $19.7 \mathrm{wt} \%$ 일 때 비표면적과 백금 분산도가 가장 높고, 그 이상의 함량에서 촉매 의 비표면적과 백금 분산도는 동일한 비율로 감소한 다. 이를 통해 백금 분산도는 촉매의 BET 비표면적 에 영향을 받으며 밀접한 관계를 갖는다는 것을 알 수 있다.

Fig. 3에는 각 제조방법을 통해 제조된 백금 촉매 의 $\mathrm{BET}$ 비표면적에 따른 백금 분산도의 변화를 나 타내었다. 상용 실리카 지지체를 쓸 때(방법 1,3 ) 보 다 sol-gel 방법(방법 2,4)에 의해 제조된 실리카 지 지체에서 $\mathrm{BET}$ 비표면적이 약 2 배 이상 증가 하였다. 또한 지르코니아를 첨가한 경우(방법 3,4 )가 미첨가 한 경우(방법 1,2 )보다 낮은 백금 분산도를 나타냈 다. 결과적으로 BET 비표면적을 증가 시킬 수 있는

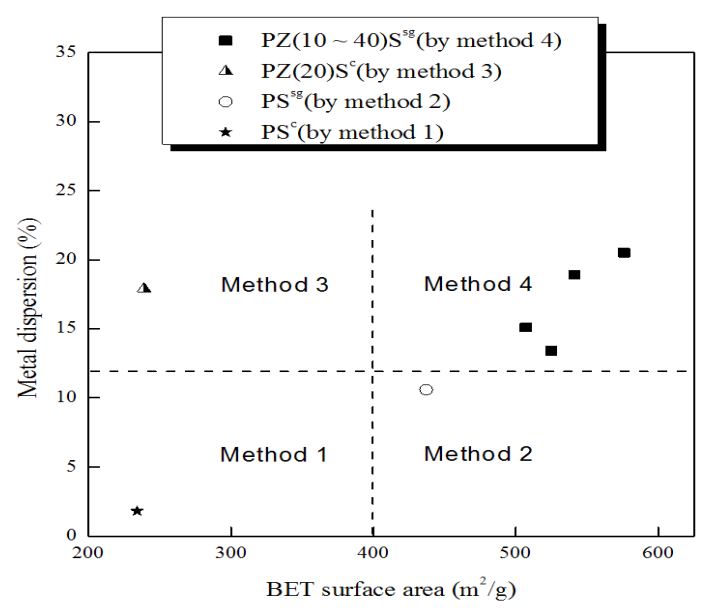

Fig. 3 Metal dispersion of Pt catalysts according to BET surface area ; each symbol presents imformation of preparation methods

지지체의 sol-gel 합성 방법과, 지르코니아의 첨가가 촉매의 비표면적을 크게 향상시킬 뿐만 아니라 백금 분산도도 증가 시킬 수 있어 방법 4에 의해 만들어진 촉매가 반응에 유리한 물성을 갖는다. 또한 방법 4에 의해 제조된 $\mathrm{PZ}(10 \sim 40) \mathrm{S}^{\mathrm{sg}}$ 촉매는 지르코니아의 함 량에 따라 BET 비표면적과 백금 분산도가 달랐다. $\mathrm{PZ}(10 \sim 40) \mathrm{S}^{\mathrm{sg}}$ 촉매는 비표면적의 증가에 기인한 백 금 분산도의 증가도 고려될 뿐만 아니라 Kim 등이 설명한 Pt-O-Zr의 결합에 의해 강화된 금속-지지체 상호작용이 있었다고 판단된다.

$\mathrm{PZ}(10 \sim 40) \mathrm{S}^{\mathrm{sg}}$ 촉매들의 XRD 결과를 Fig. 4에 나 타내었다. $\mathrm{PZ}(10) \mathrm{S}^{\mathrm{sg}}, \mathrm{PZ}(30) \mathrm{S}^{\mathrm{sg}}, \mathrm{PZ}(40) \mathrm{S}^{\mathrm{sg}}$ 촉매에서 백금 피크를 확인할 수 있었지만 $\mathrm{PZ}(20) \mathrm{S}^{\mathrm{sg}}$ 에서는 확 인할 수 없었다. 이는 백금 결정이 매우 작은 상태이 며, 분산도가 상당히 좋다는 것을 알 수 있다. $\mathrm{PZ}$ (20)S $\mathrm{S}^{\mathrm{g}}$ 촉매를 제외한 촉매들은 각각 다른 크기의 피 크들이 나타났다. 각 피크의 크기로부터 백금 결정의 크기를 예상할 수 있고, 이런 크기 변화는 Table 2에 나타난 백금 입자 크기 변화와 유사함을 알 수 있다. 따라서 첨가된 지르코니아의 함량에 따라 백금 결정 의 크기 변화가 있었고, 백금의 분산도 변화가 나타 났다고 판단된다. 


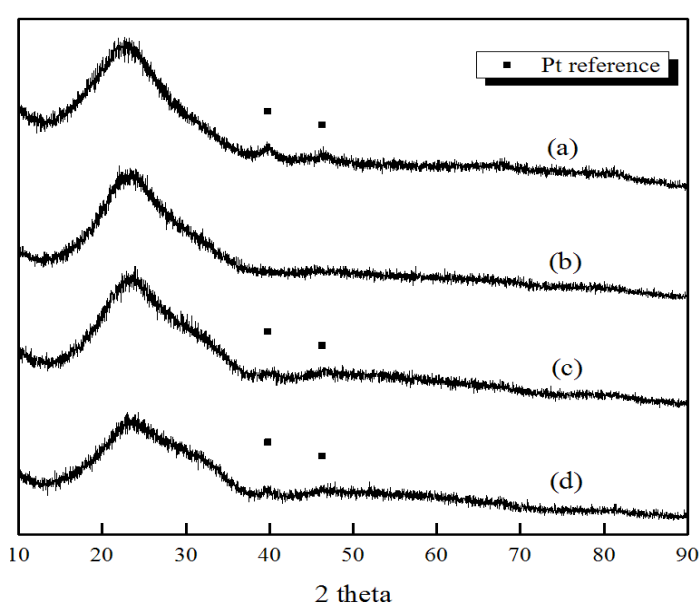

Fig. 4 XRD patterns of $\mathrm{Pt}$ catalysts made by Mehotd 4 ; (a) $P Z(10) S^{s g}$, (b) $P Z(20) S^{s g}$, (c) $P Z(30) S^{\text {sg }}$, (d) $P Z$ $(40) S^{\text {sg }}$

\subsection{HI 분해반응 특성}

$\mathrm{PS}^{\mathrm{c}}, \mathrm{PS}^{\mathrm{sg}}, \mathrm{PZ}(20) \mathrm{S}^{\mathrm{sg}}$ 의 $\mathrm{HI}$ 전환율을 Fig. 5에 나타 내었다. $\mathrm{PS}^{\mathrm{c}}$ 촉매의 최대 전환율이 $15 \%$ 정도이며, 급 격한 비활성화 후 약 $8 \%$ 의 전환율을 보이는 것을 알 수 있다. 실리카 지지체는 전이금속계 활성금속과 낮은 상호작용을 이루기 때문에 고온에서의 백금 소 결현상과 그에 따른 급격한 활성 저하 현상이 일어 난다 ${ }^{12,13)}$. 상기의 분석에서 $\mathrm{PS}^{\mathrm{c}}$ 촉매 보다 큰 $\mathrm{BET}$ 비 표면적과 백금 분산도를 나타낸 $\mathrm{PS}^{\mathrm{sg}}$ 촉매의 경우, 최대전환율과 비활성화 후 전환율이 $\mathrm{PS}^{\mathrm{c}}$ 촉매 보다 높았다. 그러나 $\mathrm{PS}^{\mathrm{sg}}$ 촉매 역시 $\mathrm{PS}^{\mathrm{c}}$ 촉매와 마찬가지로 급격한 비활성화를 보였다. 이는 단순히 sol-gel 합성 법에 의해 증가된 비표면적과 백금 분산도는 $\mathrm{HI}$ 분 해반응에서 촉매의 비활성화 억제 효과가 없는 것으 로 보인다. 실제 공정 조건에서 촉매의 반응성도 중 요하지만 촉매의 내구성이 더욱 요구된다. $\mathrm{PZ}(20)$ $\mathrm{S}^{\mathrm{sg}}$ 촉매는 가장 높은 전환율을 보여 줄 뿐만 아니라 $450^{\circ} \mathrm{C}$ 에서 열역학적 평형전환율 $21 \%$ 에 가장 가까워 다른 촉매보다 우수한 성능을 보이는 것을 알 수 있다. 또한, $\mathrm{PZ}(20) \mathrm{S}^{\mathrm{sg}}$ 촉매는 비활성화 속도도 가장 느렸고, 비활성화 과정 이후의 전환율도 $17 \%$ 로 가장 높았다.

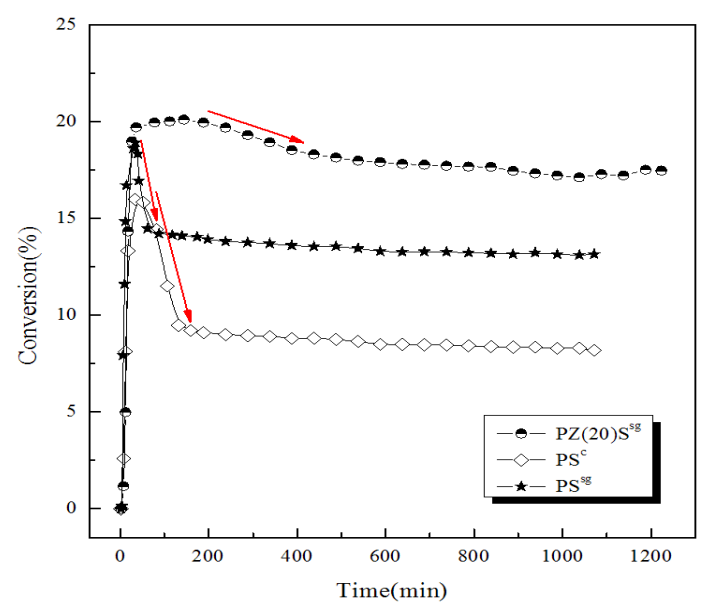

Fig. 5 Conversion of $\mathrm{HI}$ vapor using each catalysts ; comparison of common $\mathrm{Pt} /$ silica catalysts and its added $\mathrm{ZrO}_{2}$ by Method 4

\section{4. 결 론}

수소제조를 위한 황-요오드 열화학 싸이클 공정에 서 $\mathrm{HI}$ 분해반응 단계의 촉매 반응에 대한 연구를 진 행하였다. 본 연구에서 백금계 담지 촉매의 반응성 향상 및 비활성화 방지를 위한 촉매의 합성법을 제 시하였다. 합성법은 실리카의 sol-gel 합성 과정 중 겔화 단계에 지르코니아 전구체를 첨가하여 $\mathrm{ZrO}_{2}$ $\mathrm{SiO}_{2}$ 지지체를 제조 후 함침법을 이용해 백금을 담지 하는 방법(방법 4)이다. 촉매의 물성 및 $\mathrm{HI}$ 분해 반응 결과는 다음과 같다.

1) $\mathrm{Pt} / \mathrm{SiO}_{2}$ 촉매를 여러 가지 방법을 통해 제조하였 다. 각 제조 방법에 따라 촉매의 물성변화를 관찰 하였으며, 방법 4에 의해 제조된 $\mathrm{Pt} / \mathrm{ZrO}_{2}-\mathrm{SiO}_{2}{ }^{\mathrm{gg}}$ 촉매가 $\mathrm{BET}$ 비표면적 및 백금 분산도가 우수하 였다.

2) 실리카의 sol-gel 반응 중 지르코니아 전구체를 첨 가한 백금 촉매는 지르코니아의 함량에 따른 BET 비표면적의 변화를 확인하였으며, 지르코니아의 첨가량이 $20 \mathrm{wt} \%$ 일 때 가장 큰 $\mathrm{BET}$ 비표면적과 백금 분산도를 갖는다. 
3) 실리카의 so-gel 방법과 지르코니아의 첨가는 촉 매의 비표면적의 향상뿐만 아니라, 백금의 분산도 역시 증가 시키는 것을 알 수 있었다.

4) $\mathrm{HI}$ 분해반응 결과 $\mathrm{PS}^{\mathrm{c}}$ 촉매와 $\mathrm{PS}^{\mathrm{sg}}$ 촉매가 큰 비 활성화를 보였으며, $\mathrm{PZ}(20) \mathrm{S}^{\mathrm{sg}}$ 촉매에서 높은 반 응성과 비활성화 감소 효과가 나타났다. 또한 비 활성화 후에도 약 $17 \%$ 에 이르는 높은 전환율을 나타냈다.

결과적으로 실리카는 sol-gel 합성을 통해 비표면 적을 넓혀 백금 분산도와 반응성을 증가될 수 있지 만, 백금과 실리카의 상호작용이 약하기 때문에 비활 성화가 빠르게 일어난다. 그러므로 비활성화를 억제 하기 위해 금속-지지체간의 상호작용을 강화시킬 필 요가 있었다. 이를 위해 본 연구에서는 실리카의 sol-gel 합성 중 지르코니아를 첨가하여 금속-지지체 간의 상호작용을 강화하였고, $\mathrm{HI}$ 분해반응에 대한 비활성화 현상을 줄일 수 있었다.

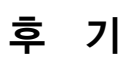

본 연구는 한국에너지기술연구원의 주요사업으로 수행한 결과이며(B3-2413-03), 원자력수소 핵심기술 개발 사업의 일환으로 추진된 것입니다(B3-6301).

\section{References}

1. D. O’Keefe, C. Allen, G. Besenbruch, L. Browon, J. Norman, and R. sharp, "Preliminary results from bench-scale testing of a sulfur-iodine thermochemical water-splitting cycle", Int. J. Hyerogen Energy, 7, 1982, p. 381.

2. J. L. Russell, K. H. McCorkle, J. H. Norman, J. T. Porter, T. S. Roemer, J. R. Schuster, R. S. Sharp, "Water splitting-A progress report", World Hydrogen Energy Conference, Vol. 1, 1976, pp. 1A105-1A124.
3. Y. Shindo, N. Ito, K. Haraya, T. Hakuta and H. Yoshitome, "Kinetics of the catalytic decomposition of hydrogen iodide in the thermochemical hydrogen production", Int. J. Hydrogen Energy, Vol. 9, No. 8, 1984, pp. 695-700.

4. C. N. Hinshelwood and R. E. Burk, "The relation of homogeneous to catalysed reactions. The catalytic decomposition of hydrogen iodide on the surface of platinum", J. Chem. Soc., Vol. 127, 1925, pp. 2896-2900.

5. I. Iida, "The kinetic behaviour of the decomposition of hydrogen iodide on the surface of platinem", Z. phys. Chem. N. F., Vol. 109, 1978, pp. 221-242.

6. Y. Oosawa, T. Kumagai, S. Mizuta, W. Kondo, Y. Takemori and K. Fujii, "Kinetics of the catalytic decomposition of hydrogen iodide in the magnesium-iodine thermochemical cycle", Bull. Chem. Soc. J., Vol. 54, 1981, pp. 742-748.

7. P. Favuzza, C. Felici, M. Lanchi, R. Liberatore, C.V. Mazzocchia, A. Spadoni, P. Tarquini, A.C. Tito, "Decomposition of hydrogen iodide in the S-I thermochemical cycle over Ni catalyst systems", INT. J. Hydrogen Energy. Vol. 34, 2009, pp. 4049-4056.

8. Yanwei Zhang, Zhihua Wang, Junhu Zhou, Jianzhong Liu, Kefa Cen, "Effect of preparation method on platinum-ceria catalysts for hydrogen iodide decomposition in sulfur-iodine cycle", INT. J. Hydrogen Energy. Vol. 33, 2008, pp. 602-607.

9. J. M. Kim. "Characteristics of HI decomposition using Pt supported catalysts and catalytic membrane reactor in sulfur-iodine process", Chung-Nam University, Daejon, Korea, 2008.

10. Y. K. Ko, C. S. Park, K.S. Kang, K. K. Bea, and Y. h. Kim, "Effect of Support in HI Decomposition Reaction using Pt Catalyst", Trans. of the Korea Hydrogen and New Energy Society, Vol 22, No. 4, 2011, pp. 415-423.

11. M. Vaarkamp, J. T. Millerb, F. S. Modica, D. C. Koningsbergerc, "On the Relation between 
Particle Morphology, Structure of the MetalSupport Interface, and Catalytic Properties of $\mathrm{Pt} /$ $\gamma-\mathrm{Al}_{2} \mathrm{O}_{3}$ ", Journal of Catalysis, Vol. 163, No. 2, 1996, pp. 294-305.

12. M.K. Oudenhuijzen, P.J. Kooyman, B. Tappel, J.A. Bokhoven, D.C. Koningsberger, "Understanding the Influence of the pretreatment Procedure on Platinum Particle Size and Particle-Size Distribution for $\mathrm{SiO}_{2}$ Impregnated with $\left[\mathrm{Pt}^{2+}\left(\mathrm{NH}_{3}\right)_{4}\right]$ $\left(\mathrm{NO}_{3}{ }^{-}\right)_{2}$ : A Combination of HRTEM, Mass Spectrometry, and Quick EXAFS”, J. Catal., Vol. 205, 2002, pp. 135-146.

13. A. Goguet, D. Schweich, J.P. Candy, "preparation of a $\mathrm{Pt} / \mathrm{SiO}_{2}$ Catalyst II. Temperature-Programmed Decomposition of the Adsorbed Platinum Tetrammine Hydroxide Complex under Flowing Hydrogen, Oxygen and Argon”, J. Catal., Vol. 220, 2003, pp. 280-290.

14. M.Y. Kim, Y.S. You, H.S. Han, G. Seo, "Preparation of Highly dispersive Platinum Catalysts Impregnated on Titania-Incorporated Silica Support", Catal. Lett., Vol. 120, 2008, pp. 40-47.

15. M.Y. Kim, S.M. Park, G. Seo, K.S. Song, "Highly Stable Platinum Catalysts in Propane Combustion Prepared by Supporting Platinum on Zirconia-Incorporated Silica", Catal. Lett., Vol. 138, 2010, pp. 205-214

16. M.Y. Kim, G. Seo, J.H. Park, C.H. Shin. and E.S. Kim "Dispersion and Stability of Platinum Catalysts Supported on Titania-, Vanadia-, Zirconiaand Ceria-Incorporated Silicas", Korean Chem. Eng. Res., Vol. 49, No. 1, 2011, pp. 1-9

17. D.W. Lee, S.J. Park, S.K. Ihm, K.H. Lee, "Synthesis of Pt-containing mesoporous silica using Pt precursor as a pore-forming agent", Journal of Non-Crystalline Solids, Vol. 353, 2007, pp. 1501-1507. 